\title{
Grindability and combustion behavior of coal and torrefied biomass blends
}

\author{
M.V. Gil, R. García, C. Pevida, F. Rubiera* \\ Instituto Nacional del Carbón, INCAR-CSIC, Apartado 73, 33080 Oviedo, Spain
}

\begin{abstract}
Biomass samples (pine, black poplar and chestnut woodchips) were torrefied to improve their grindability before being combusted in blends with coal. Torrefaction temperatures between $240-300{ }^{\circ} \mathrm{C}$ and residence times between $11-43$ min were studied. The grindability of the torrefied biomass, evaluated from the particle size distribution of the ground sample, significantly improved compared to raw biomass. Higher temperatures increased the proportion of smaller-sized particles after grinding. Torrefied chestnut woodchips $\left(280^{\circ} \mathrm{C}, 22 \mathrm{~min}\right.$ ) showed the best grinding properties. This sample was blended with coal (5-55 wt.\% biomass). The addition of torrefied biomass to coal up to 15 wt.\% did not significantly increase the proportion of large-sized particles after grinding. No relevant differences in the burnout value were detected between the coal and coal/torrefied biomass blends due to the high reactivity of the coal. $\mathrm{NO}$ and $\mathrm{SO}_{2}$ emissions decreased as the percentage of torrefied biomass in the blend with coal increased.
\end{abstract}

Keywords: Torrefaction; Biomass; Coal; Co-combustion; Grindability

\footnotetext{
* Corresponding author. Tel.: +34 985118 975; Fax: +34 985297662.

E-mail address: frubiera@incar.csic.es (F. Rubiera)
} 


\section{Introduction}

Concerns about global warming due to the greenhouse effect over the last few decades, as well as worldwide policies aimed at reducing environmentally damaging gaseous emissions to achieve a sustainable energy model, suggest the need to seek alternative renewable energy sources that can complement or partially replace fossil fuels as the main energy source. In this regard, biomass appears to be a suitable feedstock due to its global energy generation potential together with its neutrality with respect to $\mathrm{CO}_{2}$ emissions, its low $\mathrm{NO}_{x}$ and $\mathrm{SO}_{2}$ emissions and its autonomy which will contribute to reducing dependence on foreign energy (García et al., 2012).

However, raw biomass, as a potential energy source, also has certain drawbacks, stemming from to its own nature. These include its heterogeneity and low energy density (García et al., 2013). Biomass is harder to grind due to its fibrous nature and so it is difficult to reduce to small homogeneous particles, which results in a low combustion efficiency (Bridgeman et al., 2008). These drawbacks affect its handling, transportation and storage, so they must be addressed before biomass can be considered as a realistic regular energy feedstock alternative. Torrefaction is widely considered as a promising pre-treatment for reducing some of these deficiencies, since it is known to improve the solid fuel properties of biomass (Bridgeman et al., 2010).

The process of torrefaction is defined as a thermal treatment under mild conditions, i.e., a temperature between $200-300{ }^{\circ} \mathrm{C}$ (Fisher et al., 2012) and a reaction time between 30 and 180 min (Shang et al., 2012) at atmospheric pressure (Nunes et al., 2014) in an inactive (Wannapeera et al., 2011) or $\mathrm{O}_{2}$ impoverished atmosphere (3-6\% $\mathrm{O}_{2}$ ) (Wang et al., 2013) to avoid the spontaneous combustion of the treated fuel (Rousset et al., 2012). Under these conditions, a mild pyrolysis takes place, during 
which moisture is removed and between 20 to $75 \%$ of hemicellulose is converted into organic acids and low molecular weight volatile compounds (Chang et al., 2012), while structural lignin and cellulose are barely affected. The torrefaction process therefore involves several changes to the structure of the feedstock that affect some of its characteristics (Chen et al., 2015). A dry and partially carbonized solid that has a higher energy density on a mass basis is formed (Bridgeman et al., 2010). As the light volatiles are released, the percentage of carbon mass experiences a relative increase with respect to the hydrogen and oxygen contents (Bridgeman et al., 2010), which, in turn, causes an around 9-12\% increase in the higher heating value (HHV) of the biomass (Bridgeman et al., 2008; Keipi et al., 2014).

The Hardgrove Grindability Index (HGI) is the most common grindability test for coals. HGI is an indicator to check the grinding scale of coal for a coal mill and represents the difficulty for grinding the solid sample into the powder. Higher HGI value means that the sample is easier to grind into powder. After torrefaction, HGI of the samples is usually improved (Wu et al., 2012), conferring optimum grinding and pelletizing properties on the biomass (Arias et al., 2008). In this way, the energy consumption during the processing of torrefied biomass can be reduced by $40-88 \%$ compared to the treatment of raw biomass (Tapasvi et al., 2012). Bridgeman et al. (2010) in an experimental investigation of the pulverization behavior of torrefied biomass concluded that the HGI of torrefied samples was not a reliable indicator of grindability performance for some biomass samples. However, the particle size distribution of the entire ground sample provided a more satisfactory basis for analyzing grinding behavior of biomass samples. These authors also suggested that, since grindability was improved with the torrefaction process, it was possible that biomass 
could be ground with coal at increased co-grinding rates. This is a matter of some importance, since the co-grinding of both fuels would avoid the need for a separate biomass feed system and lead to a reduction in costs.

The torrefaction process provides an opportunity to increase the bulk density of the biomass by densification, which increases the homogeneity and density of the biomass almost to the level of those of coal (Du et al., 2014). This has a favorable effect on the biomass properties involved in the supply chain (transport, storage and feeding) since an easy-to-fluidize, low-hydrophobic (Stelte et al., 2013), not-prone-toagglomerate and high-energy density (up to 30\% more than that of raw biomass) feedstock is obtained (Sarvaramini et al., 2013). Thus, when the biomass is co-fired with coal in existing power stations separate handling facilities are not required (Bridgeman et al., 2008). All the benefits indicated above, which are provided by the torrefaction of biomass, justify the extra energy consumption that occurs during the process. These improved characteristics, and the low $\mathrm{CO}_{2}$ emissions that characterize biomass-based fuels, make torrefied biomass a promising feedstock for co-firing with pulverized coal in heating and power plants (Batidzirai et al., 2013). Thus, the cocombustion of biomass and coal becomes a cost-effective and efficient sustainable option for introducing renewable fuels into the energy system.

Torrefaction has received a great deal of attention in recent years. Most of the published research studies have focused on the compositional changes that occur in the raw samples during the process, as determined by proximate and ultimate analyses, on the mass loss during the biomass torrefaction and on the effect that the process conditions have on the chemical properties of the torrefied samples (Bridgeman et al., 2008; Chang et al., 2012; Keipi et al., 2014; Rousset et al., 2012; Wannapeera et al., 
2011; Wu et al., 2012). However, few studies have been reported in the literature on the improvement of biomass grindability properties as a result of torrefaction or on the combustion properties of torrefied biomass (Arias et al., 2008; Bridgeman et al., 2010; Chen et al., 2011; Phanphanich and Mani, 2011). An improvement in the grindability characteristics is expected after the torrefaction process, but the chemistry of torrefaction is also influenced by the biomass composition, which means that the local available biomass resources should be investigated in order to evaluate the feasibility of torrefaction in a particular region (Tapasvi et al., 2012).

In Spain, the co-firing of biomass in coal-fired power stations is not at present a common practice, despite the wide availability of biomass wastes, such as forest residues. Some drawbacks need to be overcome in practice for introducing torrefied biomass in coal facilities, such as that the equipment designed to burn coal should be able to easily use biomass as well, or a stable and cheap flow of biomass is needed to sustain a biomass co-firing system. The costs of biomass acquisition and transportation will determine to a large extent the economic feasibility of co-firing. Furthermore, Chen et al. (2012) highlighted that, although a number of studies on the biomass torrefaction process have been carried out in recent years, the research on the combustibility and burning characteristics of torrefied biomass is insufficient. A more exhaustive research focused on the application of the torrefied biomass needs to be therefore performed, i.e., on the co-milling and co-firing of torrefied biomass and coal, since they have been hardly considered in the literature. In light of these deficiencies, the aim of this work is to study the grindability and combustion properties of blends of coal and torrefied biomass. Torrefied biomass samples from pine, black poplar and chestnut woodchips were obtained in a tubular rotary furnace under conditions of different torrefaction 
temperature (240, 260, 280 and $\left.300{ }^{\circ} \mathrm{C}\right)$ and residence time (11, 22 and 43 minutes) in order to select the best biomass for use in co-combustion experiments with coal. The biomass was chosen on the basis of particle size distribution after grinding, since this parameter allows the grinding characteristics of the torrefied biomass samples to be compared. Both the grinding properties and the co-combustion behavior of coal/torrefied biomass blends were then studied. The burning performance of the blends was evaluated in an entrained flow reactor (EFR).

\section{Materials and methods}

\subsection{Fuel analysis}

Three raw biomasses were used in the torrefaction experiments: pine (PIN), black poplar (POP) and chestnut (CHE) woodchips. The particle size of the biomass samples used in torrefaction was $<8 \mathrm{~mm}$. A high-volatile bituminous coal (COAL) was used in the coal/biomass blend evaluation. The biomass samples were provided by Pellets Asturias, S.L., while the coal sample was supplied by EDP Spain. The data obtained from the ultimate and proximate analyses together with the higher heating values (HHV) of the raw biomass and coal samples are shown in Table 1. The proximate analysis was performed according to the standard tests CEN/TS 14775, CEN/TS 147743 and CEN/TS 15148 for moisture, volatile matter (VM) content and ash content, respectively. The fixed carbon (FC) was calculated by difference. The ultimate analysis was performed using a LECO CHN 2000 elemental analyzer to determine the $\mathrm{C}, \mathrm{N}$ and $\mathrm{H}$ mass percentages and a LECO S 114DR to determine the S content, while the O content was calculated by difference. The HHV of the samples was determined using an IKA C4000 calorimetric pump. 


\subsection{Torrefaction}

Known amounts of the three biomass samples (350-450 g) were torrefied at different temperatures (240, 260, 280 and $300^{\circ} \mathrm{C}$ ) for a residence time of 22 min under nitrogen flow. In addition, samples of chestnut woodchips were torrefied at $260{ }^{\circ} \mathrm{C}$ for residence times of 11 and $43 \mathrm{~min}$. The assessment of the effect of the residence time on the torrefaction process was performed with the chestnut sample because the most significant results from the temperature study were obtained with such biomass. The torrefaction process was performed in a Nabertherm RSR horizontal tubular rotary furnace (Fig. 1a) that consists of a ceramic tube of length $1800 \mathrm{~mm}$ and internal diameter $95 \mathrm{~mm}$, fitted with an electrical heating unit. The torrefaction temperature was controlled by three R-type thermocouples located along the furnace and connected to temperature controllers. The furnace was heated up to the required torrefaction temperature and, when it was stable, the biomass sample was fed into the tube by means of a screw feeder. During the experiments, the spin speed of the furnace was adjusted to 30, 15 and $7.5 \mathrm{rpm}$ to obtain residence times of 11, 22 and 43 min, respectively. An additional adjustment of the tilt angle from the horizontal level up to $6^{\circ}$ allowed optimum control of the residence time and prevented the accumulation of material. To refer to the torrefied samples, the torrefaction temperature and residence time are included after the biomass acronym. For example, PIN240-22 refers to the pine sample that has been torrefied at $240{ }^{\circ} \mathrm{C}$ for a residence time of $22 \mathrm{~min}$. 


\subsection{Grindability test}

Grindability was evaluated from the particle size distribution profiles of the coal and each raw and torrefied biomass sample (Bridgeman et al., 2010). A mass of $50 \mathrm{~g}$ torrefied sample was ground in a mortar grinder for 15 minutes. The ground sample was then sieved using a series of four sieves of mesh sizes 75, 150, 425 and $710 \mu \mathrm{m}$. The mass of sample collected after each sieving was measured and recorded as a percentage of the original mass sample. Then plots of the particle size distribution and cumulative particle size distribution of each ground sample were drawn. The sample that showed the highest proportion of the smallest sizes in the particle size distribution after grinding was considered as the sample with the best grindability. Once the torrefied biomass sample with the best grinding properties was chosen, mixtures of torrefied biomass and coal were prepared using proportions equal to 5, 10, 15, 30, 45 and 55 wt.\% of torrefied biomass in the blend. Both materials were mixed in the appropriate proportion and manually homogenized. Grindability was again analyzed from the particle size distribution profiles of the coal/torrefied biomass blends.

\subsection{Combustion test}

The combustion behavior of the blends of torrefied biomass (CHE280-22) and coal was studied in an EFR. The ultimate and proximate analysis data together with the higher heating values of the coal and torrefied biomass (CHE280-22) samples used in the co-firing experiments are presented in Table 1. The experimental conditions were selected so as to be able to simulate those of industrial pulverized fuel applications, including high temperature, high heating rate and short residence time. A schematic flow diagram of the experimental device used is shown in Fig. 1b. The reactor 
comprises a ceramic tube of height $1480 \mathrm{~mm}$ and internal diameter $38 \mathrm{~mm}$, which is electrically heated and able to work at a maximum temperature of $1500{ }^{\circ} \mathrm{C}$. A R-type thermocouple was used for controlling the temperature. The heating element was controlled by a PID (proportional band integral derivative) temperature controller. Firstly, the samples were oven dried at $105^{\circ} \mathrm{C}$ for $24 \mathrm{~h}$ and they were then ground and sieved to a particle size fraction of 75-150 $\mu \mathrm{m}$. Blends of 10, 20, 30 and $40 \mathrm{wt} . \%$ of torrefied biomass with coal were studied in the co-firing experiments. The fuel particles were stored in a hopper and fed in through a water-cooled injector to ensure that their temperature did not exceed $100{ }^{\circ} \mathrm{C}$ before they entered the reaction zone to avoid chemical reactions in the course of transporting the fuel particles. The particles were introduced from the top of the reactor by means of a screw feeder and made to pass along the centerline of the ceramic tube. The mass flow was controlled by the rotational speed of the screw, the particles being fed in at a rate of around $0.5 \mathrm{~g} \mathrm{~min}^{-1}$. A primary gas is also introduced through the feeding system. The combustion air (secondary air) was preheated to the oven temperature before being introduced from the top of the reactor through flow straighteners at a flow rate of $3.5 \mathrm{~L} \mathrm{~min}^{-1}$. A water-cooled collecting probe was inserted into the reaction chamber from below. A cooling nitrogen stream $(3 \mathrm{~L} / \mathrm{min}$ ) was introduced in through the top of the probe to quench the reaction products. The residual solid particles were removed by means of a cyclone and a filter situated below the sampling probe, and the exhaust gases were monitored using a battery of analyzers Emerson X-Stream X2GP $\left(\mathrm{O}_{2}, \mathrm{CO}_{2}, \mathrm{CO}, \mathrm{NO}\right.$ and $\left.\mathrm{SO}_{2}\right)$. The combustion experiments were carried out at a reactor temperature of $1300^{\circ} \mathrm{C}$ and a particle residence time of $2.5 \mathrm{~s}$. Burnout is defined as the loss of mass of a fuel during its combustion and it was expressed as the ratio of mass loss during combustion to the 
total mass of the input fuel sample. Fuel mass loss during the experiments was determined by the ash tracer method.

\section{Results and discussion}

\subsection{Grindability}

The particle size distribution plots corresponding to the untreated and torrefied PIN, POP and CHE samples after grinding are shown in Figs. 2, 3 and 4, respectively. The bar plots represent the particle size distribution between the different sieve sizes used, while the line plots show the cumulative particle size distribution as the particle size increases. In the case of the PIN biomass, Fig. 2a shows that for all the ground samples the predominant particle size is higher than $710 \mu \mathrm{m}$. After grinding, only a small fraction of the untreated sample was reduced to smaller sizes. However, it can be seen from Fig. 2b that after torrefaction, grinding became slightly easier and that the torrefied samples had a greater proportion of particle size fractions lower than $710 \mu \mathrm{m}$. Nevertheless, the effect of the torrefaction process on the grindability of the PIN biomass samples can be considered low.

In the case of the POP biomass (Fig. 3), the grinding behavior after torrefaction was similar, although the untreated sample had an initial higher proportion of small particles compared to untreated PIN. The torrefaction process also facilitated grinding to a certain extent, since the proportion of particles smaller than $425 \mu \mathrm{m}$ increased, while the proportion of larger particles decreased after the treatment. In addition, it can be seen that, as the torrefaction temperature increased, the proportion of smaller particles also slightly increased. 
Finally, Fig. 4 shows the particle size distributions for the CHE biomass samples after grinding. It can be seen that the untreated sample had a low proportion of small particles, but in this case the torrefaction treatment caused a significant increase in the proportion of particles smaller than $710 \mu \mathrm{m}$, suggesting that the average particle size had decreased. These results agree with the increase in the percentage of fine particles in the particle size distributions of torrefied biomass (Norwegian birch and spruce) found by Tapasvi et al. (2012) or the decrease in the average particle size of ground torrefied biomass observed by Phanphanich and Mani (2011).

In the present study of the CHE biomass samples, as the torrefaction temperature and the residence time increased, grinding became progressively easier. However, if the cumulative particle size distributions of the CHE240-22 and CHE260-11 samples are compared (Fig. 4b), it can be observed that after a residence time of 11 minutes grinding improved only slightly, whereas after a residence time of 22 minutes, even at a lower temperature, the proportion of small particles after grinding was much greater. When the residence time was increased from 11 to 22 minutes (see CHE260-11 and CHE26022 samples), the CHE sample experienced a huge improvement in grindability, but when the residence time was increased further to 43 minutes (i.e., CHE260-43 sample) the improvement was relatively much lower. The torrefied CHE260-43 and CHE280-22 samples were the most easily grindable, since they showed the highest increase in the fraction of particles that passed through the $75 \mu \mathrm{m}$ sieve. However, Fig. 3b shows that the CHE280-22 sample showed better grindability properties than CHE260-43. This indicates that an increase in the torrefaction temperature from 260 to $280{ }^{\circ} \mathrm{C}$ with a residence time of 22 min (see CHE260-22 and CHE280-22 samples) was more effective than an increase in the residence time from 22 to 43 minutes at a temperature of $260{ }^{\circ} \mathrm{C}$ 
(see CHE260-22 and CHE260-43 samples). As torrefaction temperature was increased, the physical properties of the biomass probably were altered at a higher extent, increasing its brittle nature and reducing its highly fibrous tenacious nature, which facilitated its grinding up to smaller sizes. Bridgeman et al. (2010) performed an investigation of the grindability of torrefied biomass (energy crops) and concluded that temperature was the most important parameter in terms of grindability of the solid product, although residence time also had a significant influence.

As mentioned above, a key objective of the present work was to select the best torrefied biomass for co-firing with coal. Accordingly, from the results obtained from the particle size distribution, the CHE280-22 sample (i.e., CHE biomass torrefied at $280^{\circ} \mathrm{C}$ for 22 minutes) was selected for the subsequent experiments on co-combustion with coal, since the CHE biomass sample treated under these conditions had shown the most remarkable improvement in grinding characteristics.

The particle size distribution profiles of the pulverized coal/torrefied CHE blends are shown in Fig. 5. In Fig. 5b it can be seen that the cumulative particle size distributions of the blends are in an intermediate position between those of the coal (100COAL) and the torrefied biomass (100CHE280-22), evidencing that upon grinding no interaction effects had occurred between the two fuels after blending. The blends of coal with torrefied CHE biomass in proportions of 5, 10 and 15 wt.\% showed a grindability behavior that was similar to that of coal for the highest particle size fractions (Fig. 5b), indicating that the addition of up to 15 wt.\% of CHE biomass did not significantly affect the particle size distribution at high sizes, as is also reflected by the smaller increase in the proportion of large particles in the case of the blends compared to coal (Fig. 5a). 


\subsection{Combustion characteristics}

The fuel properties of the torrefied biomass were evaluated by co-combustion with coal in an entrained flow reactor. The coal and its blends with torrefied biomass were burned at $1300{ }^{\circ} \mathrm{C}$ with different levels of excess oxygen. The fuel ratio, defined as the ratio between the fuel mass flow rate and the stoichiometric value, was used to determine the excess oxygen during combustion.

The burnout values of the COAL sample and its blends with the CHE280-22 torrefied biomass after air combustion are shown in Fig. 6a. The burnout decreased as the fuel ratio increased because less oxygen is available at higher fuel ratio values. However, at low values of fuel ratio (i.e., high excess oxygen) the burnout curves showed an asymptotic trend towards values close to $100 \%$, which is indicative of the high reactivity of the high-volatile bituminous coal studied (Riaza et al., 2011). This implies that no relevant differences in the burnout were found between the coal sample and the blends with different biomass concentrations at low values of fuel ratio since the coal sample reached a very high degree of burnout due to its high reactivity.

Furthermore, the reactivity of the torrefied biomass was also expected to be high, since it improved after torrefaction, as was shown in previous studies where torrefied biomass ignited more quickly than raw biomass (Bridgeman et al., 2008; Pimchuai et al., 2010; Toptas et al., 2015). Du et al. (2014) reported that the fuel properties, such as burnout degree and ignition temperature, of biomass torrefied at $300{ }^{\circ} \mathrm{C}$ were somewhere between those of a high-volatile bituminous coal and a low-volatile one.

However, at higher values of fuel ratio (i.e., lower values of excess oxygen), closer to the stoichiometric value, a slightly higher burnout was obtained for blends 
with 10-30 wt.\% of torrefied biomass compared to that reached by the coal sample. Previous studies on the co-combustion of coal/biomass blends reported an improvement in the burnout value after the addition of raw biomass to coal (Haykiri-Acma and Yaman, 2008; Munir et al., 2010; Riaza et al., 2012). Co-combustion of coal with biomass may increase the burnout due to the greater reactivity of biomass char. When two fuels with different reactivities are burned together, the more reactive fuel will react faster, thereby increasing the temperature at the top of the reaction chamber, which could lead to an improvement in the burnout of the less reactive component (Riaza et al., 2012). In the present work, the effect of the biomass on burnout was only partially detected at a low excess oxygen level, when the addition of torrefied biomass to the coal could have facilitated combustion, whereas no differences between the samples were observed at low fuel ratio values due to the high reactivity of the coal sample at the high temperature of the experiments. It can therefore be concluded that, in terms of burnout, torrefied biomass can partially replace coal fired in combustion devices. Li et al. (2012) simulated a torrefaction-based co-firing system by means of CFD modeling where high substitution ratios of torrefied biomass in a pulverized coal boiler were successfully employed without any significant decrease in boiler efficiency or fluctuation in boiler load.

The $\mathrm{NO}$ and $\mathrm{SO}_{2}$ emissions of the COAL sample and its blends with the CHE28022 torrefied biomass during combustion at $1300{ }^{\circ} \mathrm{C}$ in the entrained fuel reactor are shown in Fig. 6b and Fig. 6c, respectively. It can be seen that the NO concentration decreased as the fuel ratio increased (Fig. 6b), since the smaller amount of oxygen available at higher fuel ratios led to a reduction in coal burnout. In the case of fuel lean conditions (low values of fuel ratio) NO emissions produced during combustion were 
higher because an oxidizing atmosphere causes a greater fuel-N conversion to NO. However, in fuel-rich conditions lower NO emissions may also be attributed to the reducing atmosphere that favors the reduction of NO to molecular nitrogen via homogeneous and heterogeneous reactions (Hu et al., 2000).

NO concentrations obtained from blends of coal and torrefied biomass were lower than those achieved after coal combustion at lower values of fuel ratio, when the excess of oxygen was higher (Fig. 6b). Likewise, the NO emissions decreased slightly as the biomass percentage in the blend increased. At higher values of fuel ratio, no such clear differences between samples were found, although the NO concentration for the blend with 40 wt.\% of torrefied biomass clearly showed lower values than the coal sample. The nitrogen content of biomass is lower than that of coal. Consequently, NO emissions during co-firing might be expected to be lower than in the case of combustion of coal by itself. Li et al. (2012) also found that the $\mathrm{NO}_{x}$ emissions decreased significantly with the increasing introduction of torrefied biomass into the co-firing system.

Under air combustion, the thermal formation of NO resulting from the reaction between molecular $\mathrm{N}_{2}$ and $\mathrm{O}_{2}$ can occur at relatively high temperatures $\left(>1500^{\circ} \mathrm{C}\right)$ in fuel-lean environments. In the present study, this route may therefore have contributed to some extent to the formation of NO. In addition, NO emissions after combustion come from the formation of NO from fuel-N. During combustion, biomass releases a greater amount of volatile matter than coal. In the gas phase, the fuel nitrogen in the biomass volatiles preferably forms $\mathrm{NH}_{3}$ (Spliethoff and Hein, 1998). In contrast, HCN is assumed to be formed from bituminous coal nitrogen and it is one of the main precursors of nitrogen oxides (Spliethoff and Hein, 1998). This may have a positive impact on $\mathrm{NO}$ emissions, since $\mathrm{NH}_{3}$ acts as a reducing agent in a further reaction with 
NO to form $\mathrm{N}_{2}$. The high amount of released volatile matter from biomass combustion produces a fuel-rich condition in the atmosphere which might favor the reduction of NO. Since most of the fuel-N in coal is retained in the char and is then oxidized to NO, the $\mathrm{NH}_{3}$ originating from the biomass may lead to the reduction of $\mathrm{NO}_{x}(\mathrm{Li}$ et al., 2008). Lower emissions of NO have also been recorded when biomass is added to coals in previous works (Riaza et al., 2012; Skeen et al., 2010).

Finally, Fig. 6c shows the $\mathrm{SO}_{2}$ emissions from the combustion experiments of coal and its blends with torrefied biomass. $\mathrm{SO}_{2}$ concentrations were almost identical for all the fuel ratio values analyzed. Furthermore, no relevant differences were observed between the $\mathrm{SO}_{2}$ emissions from the coal sample and the blend with $10 \mathrm{wt}$ \% torrefied biomass. However, $\mathrm{SO}_{2}$ emissions were significantly lower in the case of the blends with 20 and 30 wt.\% torrefied biomass, and even lower for the blends with 40 wt.\%. Torrefied biomass contains considerably less sulfur than coal (Table 1), which would explain why the combustion of coal/torrefied biomass blends resulted in lower $\mathrm{SO}_{2}$ emissions. Also, $\mathrm{SO}_{2}$ could partially have been captured in the ash by alkaline-earth fractions commonly found in biomass ash (Spliethoff and Hein, 1998).

\section{Conclusions}

Grindability of biomass was assessed by the particle size distribution after pulverization. Untreated samples were difficult to pulverize. Torrefaction effectively improved grindability. Temperature was the most important parameter, but residence time also had a significant influence. The easiest sample to grind was the chestnut biomass torrefied at $280{ }^{\circ} \mathrm{C}$ for $22 \mathrm{~min}$, and this was used for co-firing with coal. Burnout values close to $100 \%$ were obtained after coal combustion and co-combustion 
of coal/torrefied biomass blends due to the inherent high reactivity of the high-

bituminous coal. Lower emissions of $\mathrm{NO}$ and $\mathrm{SO}_{2}$ were produced during co-combustion compared to coal.

\section{Acknowledgements}

This work was part of the subcontracted contribution of INCAR to a project carried out by EDP Spain with the financial support from the European Regional Development Fund (ERDF) and acting IDEPA (Economic Development Agency of the Principality of Asturias) as research funding agency (Ref.: IDE/2013/000233). The authors thank A. J. Martín, member of the PrEM group at INCAR-CSIC, for his contribution.

\section{References}

1. Arias, B., Pevida, C., Fermoso, J., Plaza, M.G., Rubiera, F., Pis, J.J., 2008. Influence of torrefaction on the grindability and reactivity of woody biomass. Fuel Process. Technol. 89, 169-175.

2. Batidzirai, B., Mignot, A.P.R., Schakel, W.B., Junginger, H.M., Faaij, A.P.C., 2013. Biomass torrefaction technology: Techno-economic status and future prospects. Energy 62, 196-214.

3. Bridgeman, T.G., Jones, J.M., Shield, I., Williams, P.T., 2008. Torrefaction of reed canary grass, wheat straw and willow to enhance solid fuel qualities and combustion properties. Fuel 87, 844-856.

4. Bridgeman, T.G., Jones, J.M., Williams, A., Waldron, D.J., 2010. An investigation of the grindability of two torrefied energy crops. Fuel 89, 3911-3918.

5. Chang, S., Zhao, Z., Zheng, A., He, F., Huang, Z., Li, H., 2012. Characterization of Products from Torrefaction of Sprucewood and Bagasse in an Auger Reactor. Energy Fuels 26, 7009-7017.

6. Chen, W.-H., Du, S.-W., Tsai, C.-H., Wang, Z.-Y., 2012. Torrefied biomasses in a drop tube furnace to evaluate their utility in blast furnaces. Bioresour. Technol. 111, 433-438.

7. Chen, W.-H., Hsu, H.-C., Lu, K.-M., Lee, W.-J., Lin, T.-C., 2011. Thermal pretreatment of wood (Lauan) block by torrefaction and its influence on the properties of the biomass. Energy 36, 3012-3021.

8. Chen, W.-H., Peng, J., Bi, X.T., 2015. A state-of-the-art review of biomass torrefaction, densification and applications. Renew. Sust. Energ. Rev. 44, 847-866. 
9. Du, S.-W., Chen, W.-H., Lucas, J.A., 2014. Pretreatment of biomass by torrefaction and carbonization for coal blend used in pulverized coal injection. Bioresour. Technol. 161, 333-339.

10. Fisher, E.M., Dupont, C., Darvell, L.I., Commandré, J.M., Saddawi, A., Jones, J.M., Grateau, M., Nocquet, T., Salvador, S., 2012. Combustion and gasification characteristics of chars from raw and torrefied biomass. Bioresour. Technol. 119, 157165.

11. García, R., Pizarro, C., Lavín, A.G., Bueno, J.L., 2013. Biomass proximate analysis using thermogravimetry. Bioresour. Technol. 139, 1-4.

12. García, R., Pizarro, C., Lavín, A.G., Bueno, J.L., 2012. Characterization of Spanish biomass wastes for energy use. Bioresour. Technol. 103, 249-258.

13. Haykiri-Acma, H., Yaman, S., 2008. Effect of co-combustion on the burnout of lignite/biomass blends: A Turkish case study. Waste Manage. 28, 2077-2084.

14. Hu, Y., Naito, S., Kobayashi, N., Hasatani, M., 2000. $\mathrm{CO}_{2}, \mathrm{NO}_{\mathrm{x}}$ and $\mathrm{SO}_{2}$ emissions from the combustion of coal with high oxygen concentration gases. Fuel 79, 1925-1932. 15. Keipi, T., Tolvanen, H., Kokko, L., Raiko, R., 2014. The effect of torrefaction on the chlorine content and heating value of eight woody biomass samples. Biomass Bioenerg. 66, 232-239.

16. Li, J., Brzdekiewicz, A., Yang, W., Blasiak, W., 2012. Co-firing based on biomass torrefaction in a pulverized coal boiler with aim of $100 \%$ fuel switching. Appl. Energy 99, 344-354.

17. Li, S., Wu, A., Deng, S., Pan, W.-p., 2008. Effect of co-combustion of chicken litter and coal on emissions in a laboratory-scale fluidized bed combustor. Fuel Process. Technol. 89, 7-12.

18. Munir, S., Nimmo, W., Gibbs, B.M., 2010. Shea meal and cotton stalk as potential fuels for co-combustion with coal. Bioresour. Technol. 101, 7614-7623.

19. Nunes, L.J.R., Matias, J.C.O., Catalão, J.P.S., 2014. A review on torrefied biomass pellets as a sustainable alternative to coal in power generation. Renew. Sust. Energ.

Rev. 40, 153-160.

20. Phanphanich, M., Mani, S., 2011. Impact of torrefaction on the grindability and fuel characteristics of forest biomass. Bioresour. Technol. 102, 1246-1253.

21. Pimchuai, A., Dutta, A., Basu, P., 2010. Torrefaction of Agriculture Residue To Enhance Combustible Properties. Energy Fuels 24, 4638-4645.

22. Riaza, J., Álvarez, L., Gil, M.V., Pevida, C., Pis, J.J., Rubiera, F., 2011. Effect of oxy-fuel combustion with steam addition on coal ignition and burnout in an entrained flow reactor. Energy 36, 5314-5319.

23. Riaza, J., Gil, M.V., Álvarez, L., Pevida, C., Pis, J.J., Rubiera, F., 2012. Oxy-fuel combustion of coal and biomass blends. Energy 41, 429-435.

24. Rousset, P., Macedo, L., Commandré, J.M., Moreira, A., 2012. Biomass torrefaction under different oxygen concentrations and its effect on the composition of the solid by-product. J. Anal. Appl. Pyrolysis 96, 86-91.

25. Sarvaramini, A., Assima, G.P., Larachi, F., 2013. Dry torrefaction of biomass Torrefied products and torrefaction kinetics using the distributed activation energy model. Chem. Eng. J. 229, 498-507.

26. Shang, L., Ahrenfeldt, J., Holm, J.K., Sanadi, A.R., Barsberg, S., Thomsen, T., Stelte, W., Henriksen, U.B., 2012. Changes of chemical and mechanical behavior of torrefied wheat straw. Biomass Bioenerg. 40, 63-70. 
27. Skeen, S.A., Kumfer, B.M., Axelbaum, R.L., 2010. Nitric Oxide Emissions during Coal and Coal/Biomass Combustion under Air-Fired and Oxy-fuel Conditions. Energy Fuels 24, 4144-4152.

28. Spliethoff, H., Hein, K.R.G., 1998. Effect of co-combustion of biomass on emissions in pulverized fuel furnaces. Fuel Process. Technol. 54, 189-205.

29. Stelte, W., Nielsen, N.P.K., Hansen, H.O., Dahl, J., Shang, L., Sanadi, A.R., 2013. Pelletizing properties of torrefied wheat straw. Biomass Bioenerg. 49, 214-221.

30. Tapasvi, D., Khalil, R., Skreiberg, Ø., Tran, K.-Q., Grønli, M., 2012. Torrefaction of Norwegian Birch and Spruce: An Experimental Study Using Macro-TGA. Energy Fuels 26, 5232-5240.

31. Toptas, A., Yildirim, Y., Duman, G., Yanik, J., 2015. Combustion behavior of different kinds of torrefied biomass and their blends with lignite. Bioresour. Technol. 177, 328-336.

32. Wang, C., Peng, J., Li, H., Bi, X.T., Legros, R., Lim, C.J., Sokhansanj, S., 2013. Oxidative torrefaction of biomass residues and densification of torrefied sawdust to pellets. Bioresour. Technol. 127, 318-325.

33. Wannapeera, J., Fungtammasan, B., Worasuwannarak, N., 2011. Effects of temperature and holding time during torrefaction on the pyrolysis behaviors of woody biomass. J. Anal. Appl. Pyrolysis 92, 99-105.

34. Wu, K.-T., Tsai, C.-J., Chen, C.-S., Chen, H.-W., 2012. The characteristics of torrefied microalgae. Appl. Energy 100, 52-57. 


\section{Figure captions}

Fig. 1. Schematic diagram of the furnace used for the torrefaction experiments (a) and of the entrained flow reactor (EFR) used for the combustion experiments (b).

Fig. 2. Particle size distribution (a) and cumulative particle size distribution (b) of the untreated and torrefied PIN samples after grinding.

Fig. 3. Particle size distribution (a) and cumulative particle size distribution (b) of the untreated and torrefied POP samples after grinding.

Fig. 4. Particle size distribution (a) and cumulative particle size distribution (b) of the untreated and torrefied CHE samples after grinding.

Fig. 5. Particle size distribution (a) and cumulative particle size distribution (b) of the COAL sample, CHE280-22 sample and their blends after grinding.

Fig. 6. Burnout values (a), $\mathrm{NO}$ (b) and $\mathrm{SO}_{2}$ (c) emissions of the COAL sample and its blends with the CHE280-22 torrefied biomass for combustion at $1300{ }^{\circ} \mathrm{C}$ at different fuel ratios in an entrained fuel reactor. 
Table 1

Ultimate and proximate analyses and higher heating value of the raw biomass samples

\begin{tabular}{llllll}
\hline Sample & PIN & POP & CHE & COAL & CHE280-22 \\
\hline Moisture (wt.\%) & $8.9 \pm 0.12$ & $10.0 \pm 0.60$ & $9.2 \pm 0.39$ & $6.0 \pm 0.65$ & $5.8 \pm 0.41$ \\
\hline Ultimate analysis (wt.\%, db) & & & & & \\
\hline C & $50.60 \pm 0.19$ & $49.85 \pm 0.35$ & $49.66 \pm 0.17$ & $75.75 \pm 0.25$ & $51.26 \pm 0.29$ \\
H & $6.04 \pm 0.03$ & $5.89 \pm 0.04$ & $5.64 \pm 0.14$ & $5.03 \pm 0.19$ & $5.33 \pm 0.03$ \\
N & $0.30 \pm 0.02$ & $0.39 \pm 0.01$ & $0.26 \pm 0.02$ & $1.73 \pm 0.08$ & $0.29 \pm 0.03$ \\
$\mathrm{O}^{\text {a }}$ & $42.65 \pm 0.35$ & $42.75 \pm 0.44$ & $44.13 \pm 0.22$ & $10.15 \pm 0.49$ & $42.31 \pm 0.29$ \\
S & $0.01 \pm 0.00$ & $0.02 \pm 0.01$ & $0.01 \pm 0.00$ & $0.64 \pm 0.06$ & $0.01 \pm 0.00$ \\
\hline Proximate analysis (wt.\%, db) & & & & & \\
\hline Ash & $0.4 \pm 0.12$ & $1.1 \pm 0.14$ & $0.3 \pm 0.15$ & $6.7 \pm 0.28$ & $0.8 \pm 0.09$ \\
FC & $15.2 \pm 0.54$ & $16.6 \pm 0.33$ & $17.4 \pm 0.64$ & $54.6 \pm 0.63$ & $20.0 \pm 0.34$ \\
VM & $84.4 \pm 0.56$ & $82.3 \pm 0.19$ & $82.3 \pm 0.75$ & $38.7 \pm 0.48$ & $79.2 \pm 0.88$ \\
\hline HHV (MJ/kg, db) & $19.9 \pm 0.07$ & $19.6 \pm 0.14$ & $19.1 \pm 0.31$ & $31.3 \pm 0.34$ & $19.6 \pm 0.70$
\end{tabular}

db: dry basis; FC: fixed carbon; VM: volatile matter; HHV: higher heating value.

${ }^{\text {a }}$ Calculated by difference. 
(a)

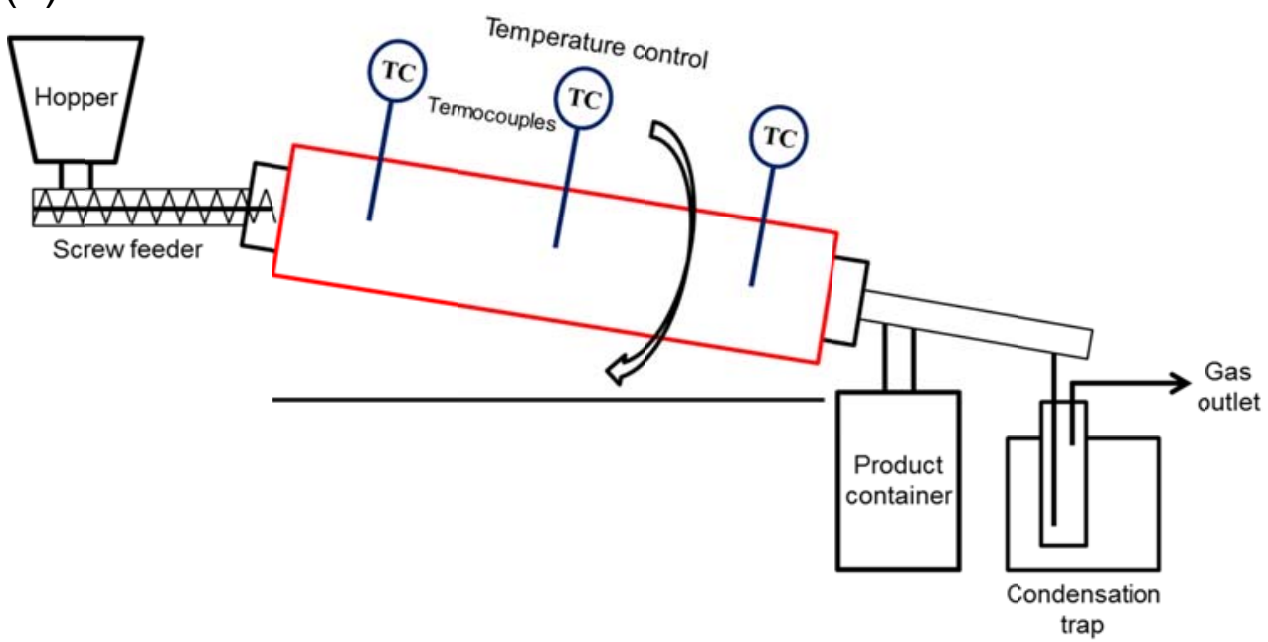

(b)

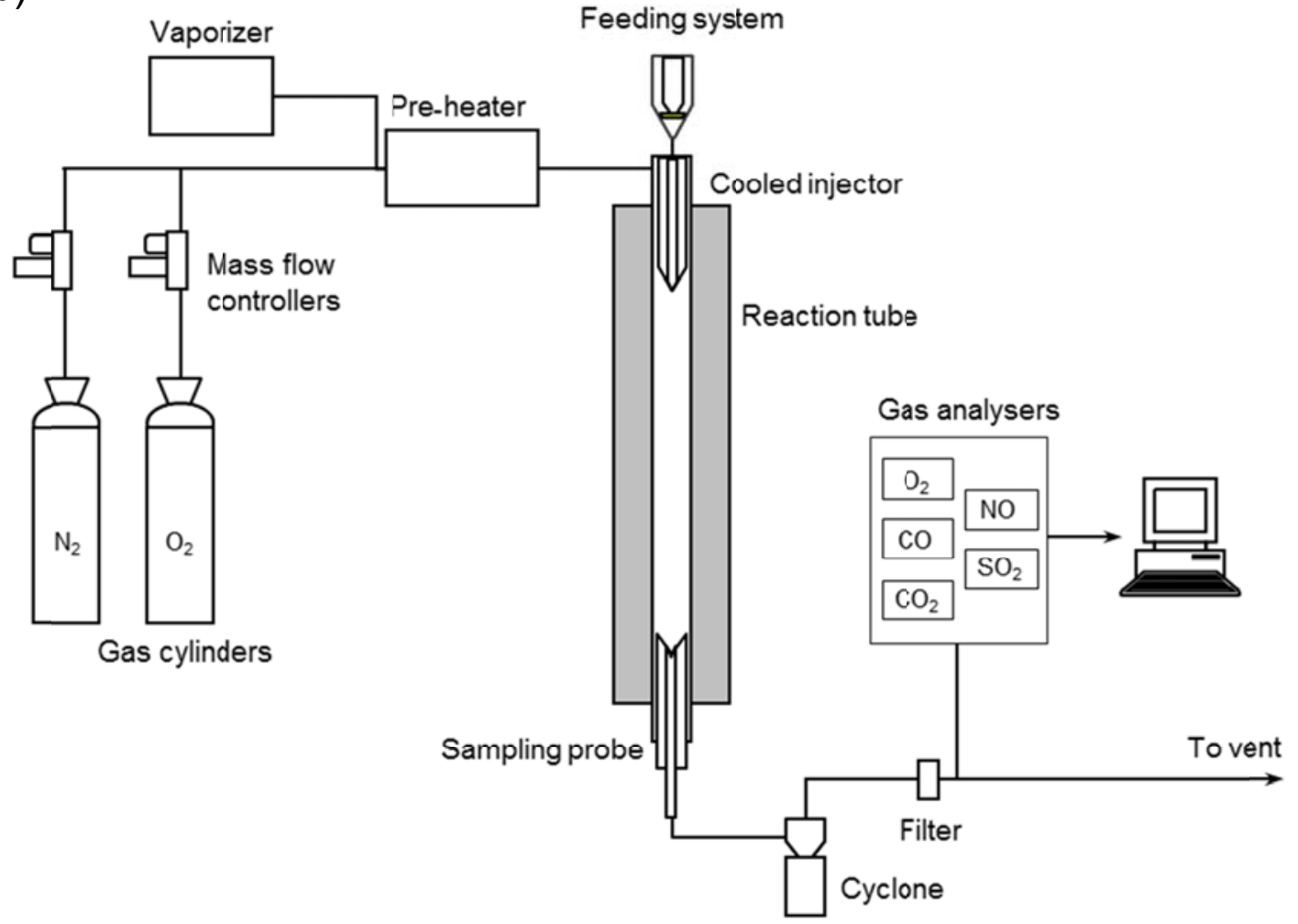

Fig. 1. Schematic diagram of the furnace used for the torrefaction experiments (a) and of the entrained flow reactor (EFR) used for the combustion experiments (b). 

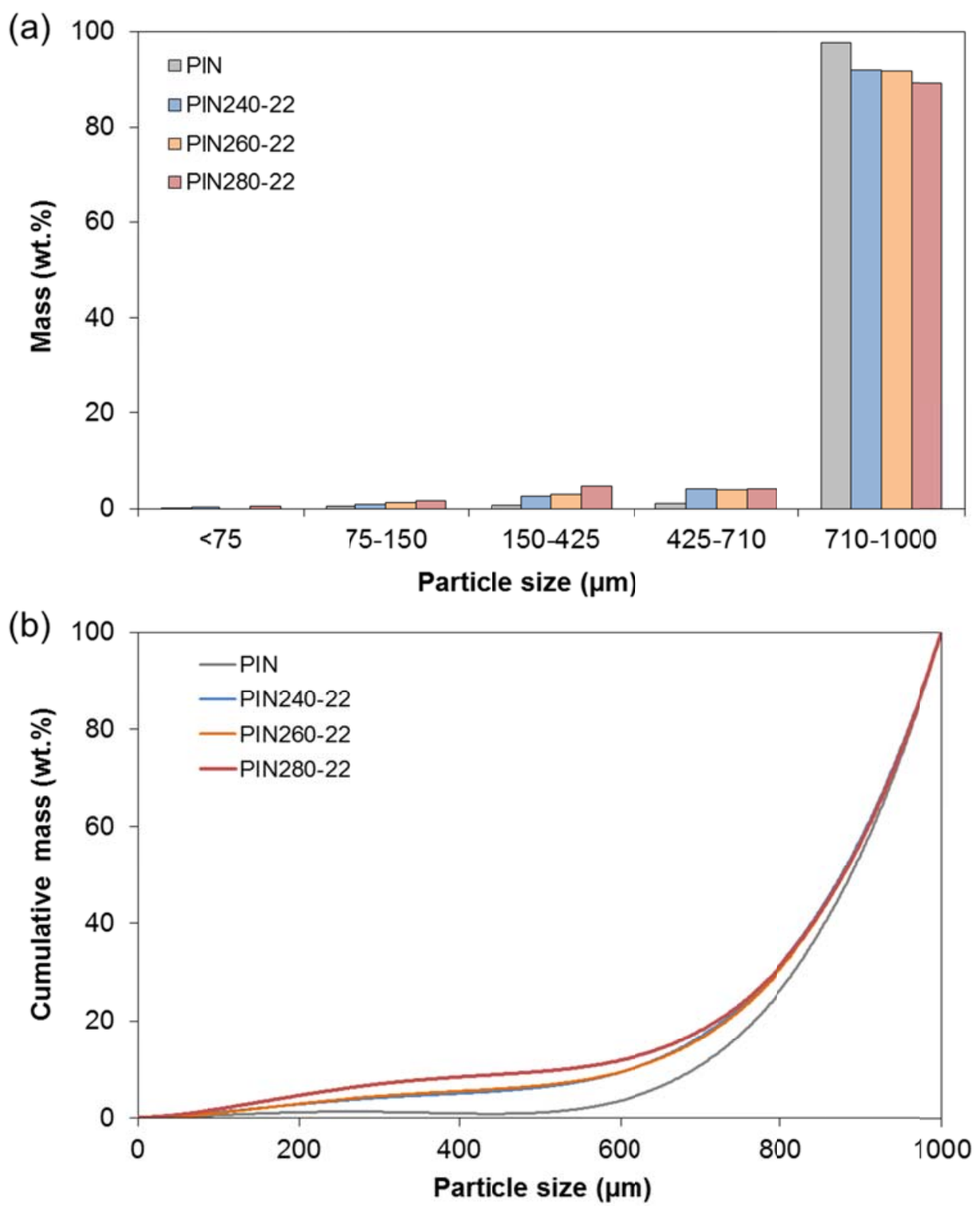

Fig. 2. Particle size distribution (a) and cumulative particle size distribution (b) of the untreated and torrefied PIN samples after grinding. 

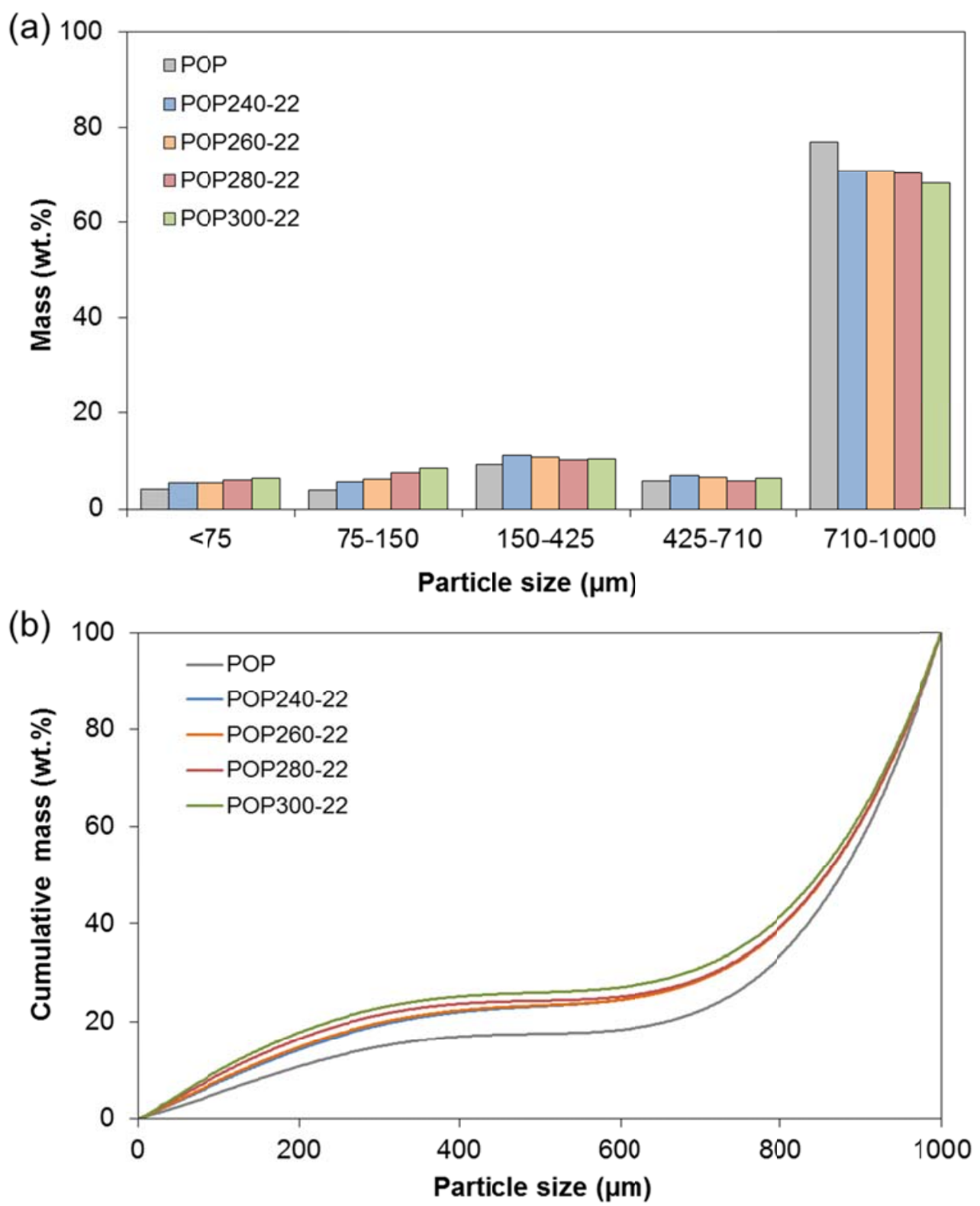

Fig. 3. Particle size distribution (a) and cumulative particle size distribution (b) of the untreated and torrefied POP samples after grinding. 

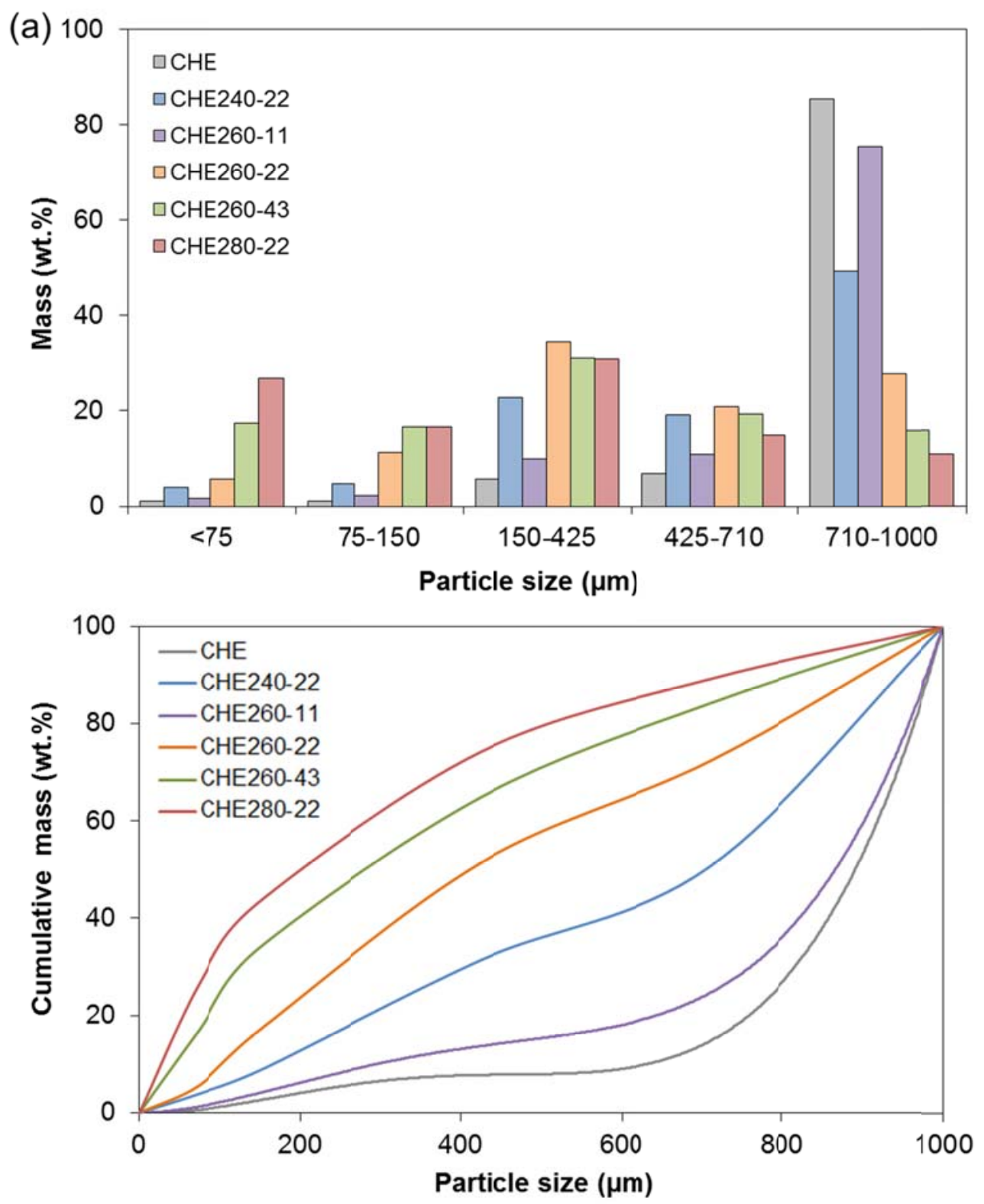

Fig. 4. Particle size distribution (a) and cumulative particle size distribution (b) of the untreated and torrefied CHE samples after grinding. 

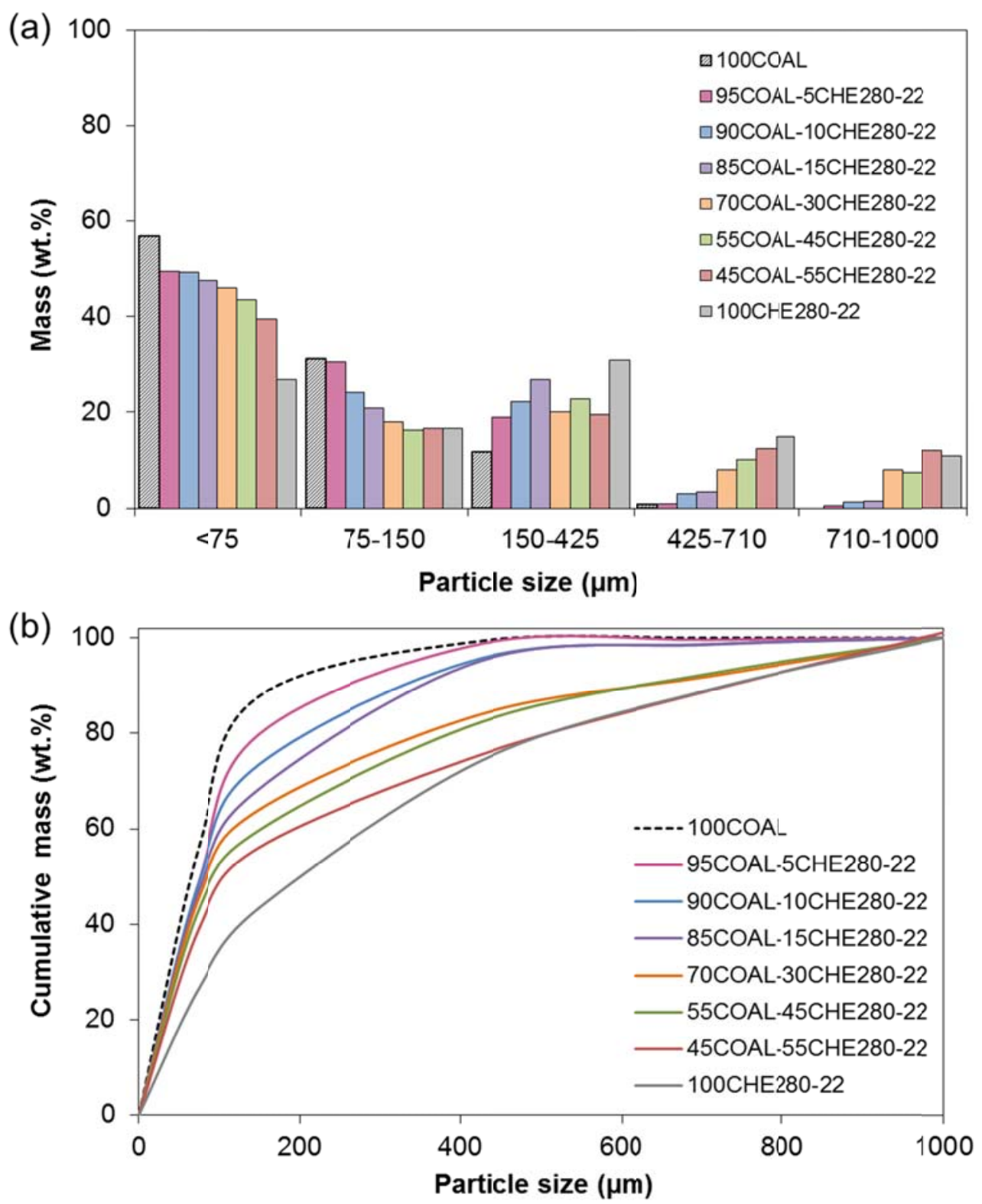

Fig. 5. Particle size distribution (a) and cumulative particle size distribution (b) of the COAL sample, CHE280-22 sample and their blends after grinding. 

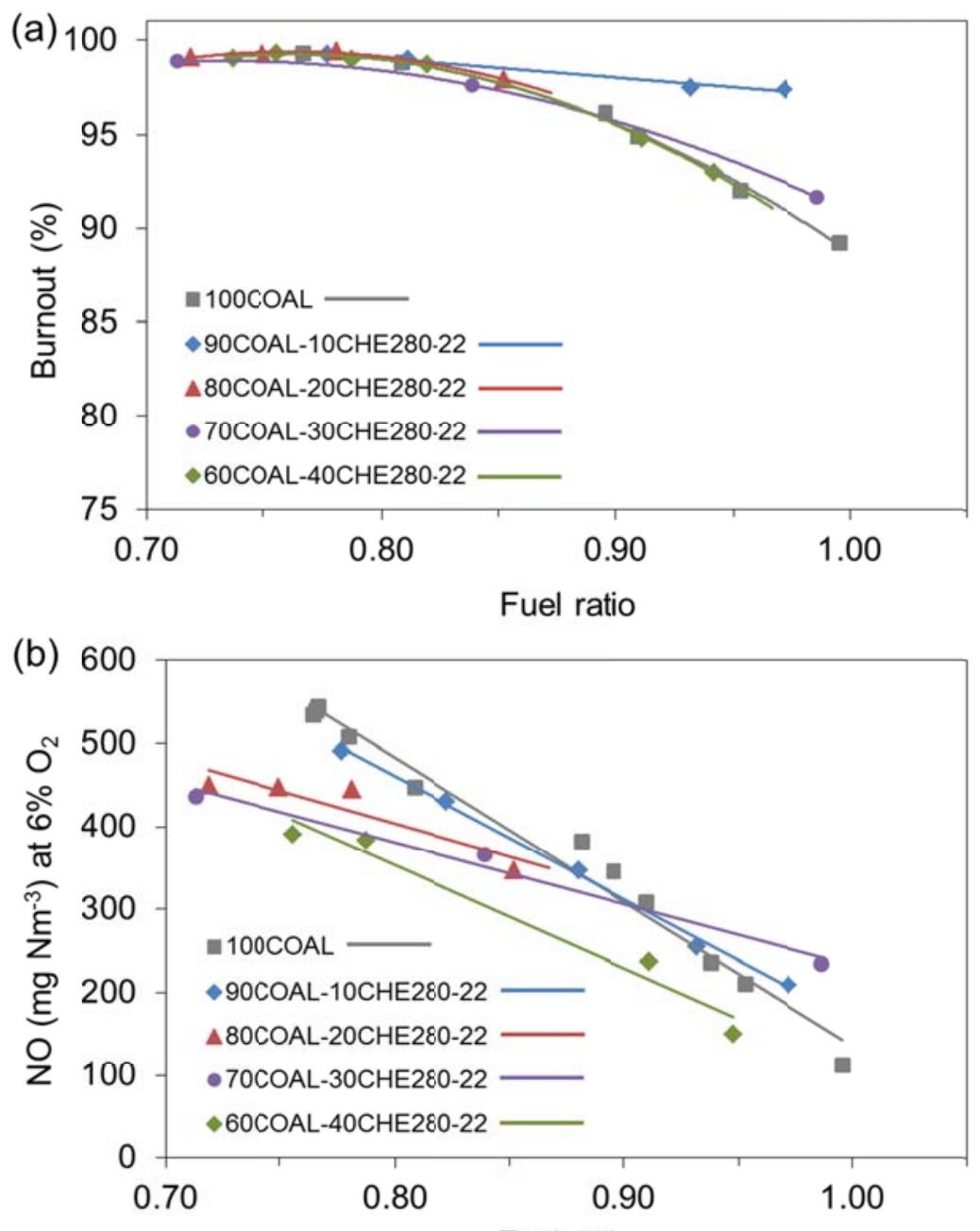

Fuel ratio

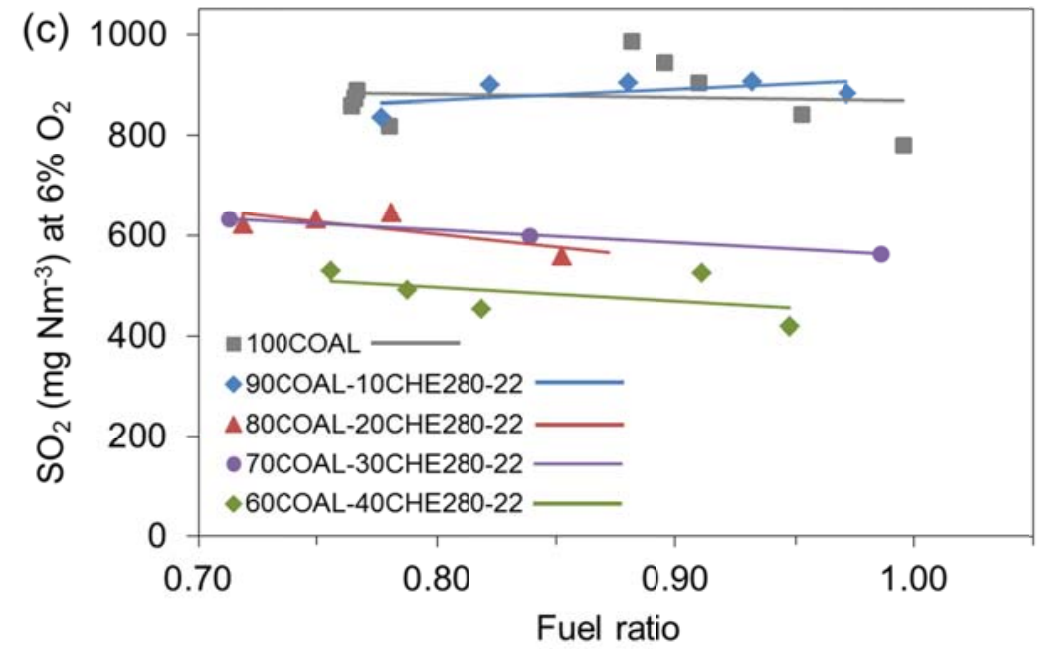

Fig. 6. Burnout values (a), $\mathrm{NO}$ (b) and $\mathrm{SO}_{2}$ (c) emissions of the COAL sample and its blends with the CHE280-22 torrefied biomass for combustion at $1300{ }^{\circ} \mathrm{C}$ at different fuel ratios in an entrained fuel reactor. 